\title{
Correction to: Progression of frailty and prevalence of osteoporosis in a community cohort of older women-a 10-year longitudinal study
}

\author{
P. Bartosch ${ }^{1,2} \cdot$ F. E. McGuigan ${ }^{1,2} \cdot$ K. E. Akesson ${ }^{1,2}$
}

Published online: 25 February 2019

(C) The Author(s) 2019

\section{Correction to: Osteoporosis International (2018)} https://doi.org/10.1007/s00198-018-4593-7

The Open Access license, which previously read:

Open Access This article is distributed under the terms of the Creative Commons Attribution-NonCommercial 4.0 International License (http://creativecommons.org/licenses/ by-nc/4.0/), which permits any noncommercial use, distribution, and reproduction in any medium, provided you give appropriate credit to the original author(s) and the source, provide a link to the Creative Commons license, and indicate if changes were made.

Should read:

The original article got updated

The online version of the original article can be found at https://doi.org/ 10.1007/s00198-018-4593-7

\section{K. E. Akesson}

kristina.akesson@med.lu.se

1 Lund University, Department of Clinical Sciences Malmö, Clinical and Molecular Osteoporosis Research Unit, 20502 Malmö, Sweden

2 Department of Orthopaedics, Skåne University Hospital, 205 02 Malmö, Sweden
Open Access This article is distributed under the terms of the Creative Commons Attribution 4.0 International License (http://creativecommons.org/licenses/by/4.0/), which permits unrestricted use, distribution, and reproduction in any medium, provided you give appropriate credit to the original author(s) and the source, provide a link to the Creative Commons license, and indicate if changes were made. Medium, provided you give appropriate credit to the original author(s) and the source, provide a link to the Creative Commons license, and indicate if changes were made

Publisher's note Springer Nature remains neutral with regard to jurisdictional claims in published maps and institutional affiliations. 